Research article Open Access

\title{
Epigenetic silencing and deletion of the BRCA1 gene in sporadic breast cancer
}

\author{
Valgerdur Birgisdottir ${ }^{1,2}$, Olafur A Stefansson ${ }^{1,2}$, Sigridur K Bodvarsdottir ${ }^{1,2}$, \\ Holmfridur Hilmarsdottir ${ }^{1,2}$, Jon G Jonasson ${ }^{2,3,4}$ and Jorunn E Eyfjord ${ }^{1,2}$
}

\author{
${ }^{1}$ The Icelandic Cancer Society, Molecular and Cell Biology Research Laboratory, Reykjavik, Iceland \\ 2University of Iceland Department of Medicine, Reykjavik, Iceland \\ ${ }^{3}$ The Icelandic Cancer Registry, Reykjavik, Iceland \\ ${ }^{4}$ University Hospital Department of Pathology, Reykjavik, Iceland
}

Corresponding author: Jorunn E Eyfjord, jorunn@krabb.is

Received: 15 Feb 2006 Revisions requested: 22 Mar 2006 Revisions received: 16 Jun 2006 Accepted: 26 Jun 2006 Published: 17 Jul 2006

Breast Cancer Research 2006, 8:R38 (doi:10.1186/bcr1522)

This article is online at: http://breast-cancer-research.com/content/8/4/R38

(c) 2006 Birgisdottir et al.; licensee BioMed Central Ltd.

This is an open access article distributed under the terms of the Creative Commons Attribution License (http://creativecommons.org/licenses/by/2.0), which permits unrestricted use, distribution, and reproduction in any medium, provided the original work is properly cited.

\begin{abstract}
Introduction $B R C A 1$ or $B R C A 2$ germline mutations increase the risk of developing breast cancer. Tumour cells from germline mutation carriers have frequently lost the wild-type allele. This is predicted to result in genomic instability where cell survival depends upon dysfunctional checkpoint mechanisms. Tumorigenic potential could then be acquired through further genomic alterations. Surprisingly, somatic $B R C A$ mutations are not found in sporadic breast tumours. BRCA1 methylation has been shown to occur in sporadic breast tumours and to be associated with reduced gene expression. We examined the frequency of $B R C A 1$ methylation in 143 primary sporadic breast tumours along with $B R C A 1$ copy number alterations and tumour phenotype.

Methods Primary sporadic breast tumours were analysed for $B R C A 1 \alpha$ promoter methylation by methylation specific PCR and for allelic imbalance (Al) at BRCA1 and BRCA2 loci by microsatellite analysis and TP53 (also known as p53) mutations by constant denaturing gel electrophoresis. The BRCA1 methylated tumours were analysed for $B R C A 1$ copy alterations by fluorescence in situ hybridisation and BRCA1 expression by immunostaining.
\end{abstract}

Results BRCA1 methylation was found in 13/143 (9.1\%) sporadic breast tumours. The BRCA1 methylated tumours were significantly associated with estrogen receptor (ER) negativity
$(\mathrm{P}=0.0475)$ and displayed a trend for $\mathrm{BRCA1} \mathrm{Al}(\mathrm{P}=0.0731)$ as well as young-age at diagnosis $(\leq 55 ; \mathrm{P}=0.0898) . B R C A 1$ methylation was not associated with BRCA2 Al $(\mathrm{P}=0.5420)$, although a significant association was found between $B R C A 1$ $\mathrm{Al}$ and BRCA2 $\mathrm{Al}(\mathrm{P}<0.0001)$.

Absent/markedly reduced BRCA1 expression was observed in 9/13 BRCA1 methylated tumours, most of which had BRCA1 deletion. An elevated TP53 mutation frequency was found among BRCA1 methylated tumours (38.5\%) compared with non-methylated tumours (17.2\%). The BRCA1 methylated tumours were mainly of tumour grade 3 (7/13) and infiltrating ductal type (12/13). Only one methylated tumour was of grade 1.

Conclusion $B R C A 1$ methylation is frequent in primary sporadic breast tumours. We found an indication for $B R C A 1$ methylation to be associated with $\mathrm{Al}$ at the BRCA1 locus. Almost all BRCA1 methylated tumours with absent/markedly reduced BRCA1 expression (8/9) displayed BRCA1 deletion. Thus, epigenetic silencing and deletion of the BRCA1 gene might serve as Knudson's two 'hits' in sporadic breast tumorigenesis. We observed phenotypic similarities between $B R C A 1$ methylated and familial BRCA1 tumours, based on BRCA1 deletion, TP53 mutations, ER status, young age at diagnosis and tumour grade.

\section{Introduction}

Germline mutations in one allele of the BRCA1 or BRCA2 genes significantly increase the risk of developing early-onset breast cancer [1]. Tumour cells from predisposed individuals have consistently lost the wild-type BRCA allele [2,3]. The most prominent feature of BRCA deficient cells is the inability

$\overline{\mathrm{Al}}=$ allelic imbalance $\mathrm{Cl}=$ confidence interval; $\mathrm{ER}=$ estrogen receptor; $\mathrm{FISH}=$ fluorescence in situ hybridisation; $\mathrm{OR}=$ odds ratio; $\mathrm{PR}=$ progesterone receptor. 
to repair DNA cross-links and DNA double-strand breaks by error-free homologous recombination, which probably underlies genomic instability and cancer predisposition [4]. Survival of BRCA deficient cells is generally thought to be dependent upon dysfunctional checkpoint mechanisms, in which case tumorigenic potential could be acquired through additional genomic rearrangements and gene mutations. Indeed, familial BRCA1 tumours are associated with mutations in the TP53 checkpoint gene, supporting the notion that genomic instability is an important driving force in early-onset familial BRCA1 tumorigenesis [5].

Although inherited cancer syndromes are rare, the genes accounting for them are generally believed to play an important role in sporadic cancer. It was anticipated, therefore, that somatic BRCA mutations would be found to contribute to sporadic breast carcinogenesis. Surprisingly, somatic $B R C A$ gene mutations have not been found in sporadic breast tumours $[6,7]$. On the other hand, allelic imbalance $(\mathrm{Al})$ at the $B R C A$ loci, an indicator for loss of heterozygosity, is know to be a fairly common event in breast cancer [8]. The implications of $\mathrm{Al}$ at the BRCA loci are unknown since Knudson's hypothesis predicts an additional inactivating event on top of $A l$ to be required for tumorigenesis to occur [9]. For these reasons, the involvement of the BRCA genes in sporadic breast tumours has been questioned. An alternative mechanism for BRCA1 inactivation has been suggested to be gene silencing by epigenetic mechanisms. Hypermethylation of CpG-island promoters is known to be strongly associated with gene silencing. Once established, methylation is passed on to daughter cells during DNA replication by the activity of DNA methyltransferases, thereby conserving the overall pattern of methylated CpG-islands [10]. The methylation patterns of virtually all types of cancer, including breast carcinoma, have been found to differ extensively from that of the corresponding normal tissue. These alterations are cancer-type specific and include global genomic hypomethylation as well as non-random hypermethylation of normally unmethylated CpG-island promoters $[11,12]$. These observations, and others, indicate that epigenetic modifications could be important in cancer etiology [13].

Several studies have reported hypermethylation of the BRCA1 promoter in sporadic breast and ovarian tumours. Furthermore, BRCA1 methylation has only been found in breast and ovarian tumours and has been associated with $\mathrm{Al}$ at the $B R C A 1$ locus and reduced BRCA1 gene expression [12,14]. $B R C A 2$ promoter hypermethylation has not been found in breast tumours, although it has been reported in ovarian tumours $[15,16]$.

Familial BRCA1 and BRCA2 tumours are associated with young age of onset and are phenotypically distinct from each other as well as from sporadic breast tumours [1,17-19]. Conventional histopathological and molecular analyses have demonstrated familial BRCA1 tumours to have a basal-like phenotype and to be significantly associated with certain features, such as $\mathrm{Al}$ at the BRCA1 locus, a negative estrogen receptor (ER) and progesterone receptor (PR) status, a medullary tumour histological type, TP53 mutations and, depending on the mutation involved, a high tumour grade $[3,5,18,20,21]$. Interestingly, gene expression profiling has revealed similarities between $B R C A 1$ methylated and familial BRCA1 tumours [17,22]. Similarly, a comparative genomic hybridisation study has reported a specific pattern of genetic alterations to be predictive of familial BRCA1 tumours and BRCA1 methylated tumours [23]. This lends support to the idea that epigenetic silencing of the BRCA1 gene might channel tumour progression, akin to an underlying $B R C A 1$ germline mutation resulting in a BRCA-like phenotype. However, a recent report showing high levels of BRCA1 expression and a low frequency of BRCA1 promoter methylation in basal-like sporadic tumours suggests that this might be more complex [24].

In the present study, we examined the frequency of $B R C A 1 \alpha$ promoter hypermethylation in 143 unselected primary sporadic breast tumours. All tumours were analysed for $\mathrm{Al}$ at the BRCA1 and BRCA2 loci, TP53 mutations, hormonal receptor status and age at diagnosis. Copy number alterations at the $B R C A 1$ locus were further examined by fluorescence in situ hybridisation (FISH) in the BRCA1 methylated tumours which were also analysed for BRCA1 protein expression, histological type and tumour grade. The purpose of the study was to examine whether the BRCA1 gene could be implicated in sporadic breast tumorigenesis through epigenetic modifications.

\section{Materials and methods Study group}

The study group consisted of 143 female breast cancer patients that carried neither the lcelandic BRCA1 5193G $\rightarrow \mathrm{A}$ nor the BRCA2 999del5 germline mutations [25,26]. DNA samples from these patients were obtained from the Biological Specimen Bank of the Icelandic Cancer Society. Tumour DNA (obtained from fresh/frozen primary breast cancer tissue) and normal DNA (obtained from blood or from fresh/frozen breast tissue adjacent to the breast cancer tissue) were available from each of the patients. Data on tumour grade (Nottingham tumour grade), histological type, ER and PR status, flow-cytometric DNA index and aneuploidy of the tumours were obtained from the Department of Pathology, Landspitali University Hospital (Reykjavik, Iceland). This work was carried out according to permits from the Icelandic Data Protection Commission $(2004040264 ; 200403147)$ and Bioethics Committee (99041V2S1; 99111V1S1).

\section{Methylation specific PCR}

DNA methylation of the BRCA1 promoter region was assessed by methylation specific PCR of sodium bisulphite treated DNA [27]. Tumour DNA and controls $(1 \mu \mathrm{g})$ were treated with sodium bisulphite and purified using the Wizard 
(a)

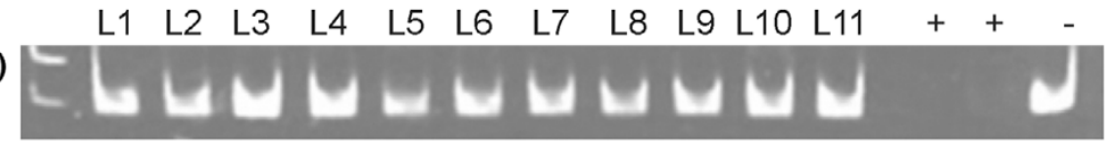

(b)

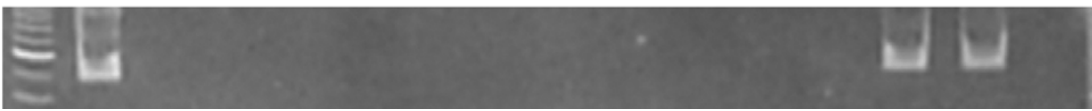

Methylation-specific PCR analysis of the BRCA1 promoter region. Positive (+) and negative (-) controls are seen on the far right. Each lane contains products generated from separate PCR reactions using primers specific for (a) non-methylated and (b) methylated $B R C A 1$ alleles. The tumour sample in lane 1 (L1) shows the presence of a band in both PCR reactions, indicating methylation of the BRCA1 promoter region.

DNA Clean-Up System (catalogue no. A7280, Promega, Madison, WI) following the manufacturer's recommendations. Modified DNA was amplified with published PCR primers that distinguish unmethylated and methylated DNA. Primer sequences for unmethylated and methylated DNA were as follows: unmethylated forward, ggt taa ttt aga gtt ttg aga gat $\mathrm{g}$; unmethylated reverse, t caa caa act cac acc aca caa tca; methylated forward, ggt taa ttt aga gtt tcg aga gac g; and methylated reverse, tca acg aac tca cgc cgc gca atc $g$ [28]. The primers amplified a 182 base-pair (bp) product corresponding to nucleotides -150 to +32 relative to the main transcription start site of BRCA1. DNA extracted from blood was used as a negative control for methylated BRCA 1 alleles. DNA extracted from blood and methylated in vitro was used as a positive control. The PCR solution $(15 \mu \mathrm{l})$ contained $1 \mu \mathrm{l}$ of modified DNA in 1X Thermo-Start PCR Master Mix (ABgene, Epsom, UK) and 5 pmol of each primer. The PCR was carried out in a thermocycler with the following conditions: one cycle of $95^{\circ} \mathrm{C}$ for 15 minutes followed by 35 cycles of $94^{\circ} \mathrm{C}$ for $30 \mathrm{~s}, 65^{\circ} \mathrm{C}$ for $30 \mathrm{~s}$ and $72^{\circ} \mathrm{C}$ for $60 \mathrm{~s}$, ending with one cycle of $72^{\circ} \mathrm{C}$ for 5 minutes. Then, $6 \mu$ of the PCR product were mixed with $6 \mu \mathrm{l}$ of $1 \mathrm{X}$ loading buffer ( $98 \%$ formamide, $0.1 \%$ xylene cyanol, $0.1 \%$ bromophenol blue and $10 \mathrm{mM}$ EDTA) and electrophorised on $7.5 \%$ polyacrylamide gels.

\section{Allelic imbalance by microsatellite analysis}

$\mathrm{Al}$ at polymorphic microsatellite markers was analysed by laser quantification of PCR products. We analysed two intragenic BRCA1 markers (D17S855 and D17S1323), located within introns 12 and 20, respectively, and one marker centromeric to the BRCA1 gene (D17S846) located in region 17q12. Two $B R C A 2$ markers were analysed, located in region $13 q 12$, centromeric (D13S260) and telomeric (D13S171) to the gene. The marker primers were of published sequences available from The GDB Human Genome Data Base [29]. The primers were purchased HPLC purified from Eurogentec (Seraing, Belgium) with the forward primers Cy5 indocarbocyanin labelled.

The PCR solution $(15 \mu \mathrm{l})$ contained $50 \mathrm{ng}$ of DNA, $5 \mathrm{pmol}$ of each primer, $0.2 \mathrm{mM}$ Ultrapure dNTPs (Amersham Pharmacia, Little Chalfont, Buckinghamshire, UK) and 0.36U Dynazyme enzyme mix (Finnzymes, Espoo, Finland) with supplied 1X reaction buffer. A Hot Start was performed by heating the PCR solution in a thermocycler at $94^{\circ} \mathrm{C}$ for 2 minutes and cooling to $85^{\circ} \mathrm{C}$ before the enzyme was added to the solution. This was followed by 30 cycles at $94^{\circ} \mathrm{C}$ for $30 \mathrm{~s}, 64^{\circ} \mathrm{C}$ to $69^{\circ} \mathrm{C}$ (annealing temperature varied depending on which primers were used) for $30 \mathrm{~s}$ and $72^{\circ} \mathrm{C}$ for $60 \mathrm{~s}$, ending with 1 cycle of $72^{\circ} \mathrm{C}$ for 5 minutes.

The PCR products were mixed in a stop solution $(100 \%$ deionized formamide and Dextran Blue 2000 (5 mg/ml); Amersham Pharmacia) in ratios varying from 0.13 to 1 , denatured at $95^{\circ} \mathrm{C}$ for 5 minutes and resolved on a $3 \mathrm{~mm}$ thick High Resolution Reprogel (Amersham Pharmacia) using an automated laser fluorescent sequencer (ALF Express DNA Sequencer, Amersham Pharmacia). Aliquots of 3 to $5 \mu$ of each sample were loaded onto the gel. The following running parameters were used: $1,500 \mathrm{~V}, 60 \mathrm{~mA}, 25 \mathrm{~W}, 55^{\circ} \mathrm{C}$. The sample interval was $2 \mathrm{~s}$, the running time 300 minutes and the running buffer 1X TBE (Tris-BoricAcid-EDTA). ALFwin Fragment analyser 1.0 software (Amersham Parmacia) was used to compare the relative quantity of the $\mathrm{PCR}$ products. Al was defined if the relative difference of peaks representing alleles in the tumour and the corresponding normal DNA reactions was more than $25 \%$.

\section{Fluorescence in situ hybridization}

FISH analysis was performed on paraffin embedded and formalin fixed breast tumour tissue sections (sliced in $4 \mu \mathrm{m} \mathrm{sec}-$ tions) using DNA probes for the BRCA1 region and the centromere region of chromosome 17, simultaneously. The probe for the BRCA1 region (PAC103014; the Human BAC Clone Library, Sanger Centre, Hinxton, Cambridge, UK) which spans the entire BRCA1 gene was labelled with SpectrumOrange-dUTP (Vysis, Des Plaines, IL, USA) by nick-translation. Hybridisation efficiency of the BRCA1 probe has previously been tested in non-malignant breast samples [30]. The probe for the centromere region of chromosome 17 (clone D17Z1 in pUC 19: American Type Culture Collection, USA), was used as a copy number reference for $B R C A 1$ and labelled with green fluoroscein-11-dUTP (Amersham Pharmacia) by nicktranslation. 
(a)
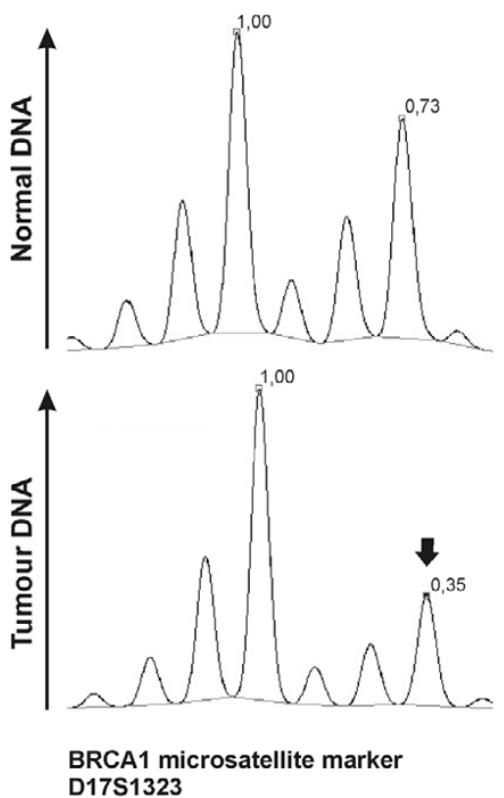

(b)
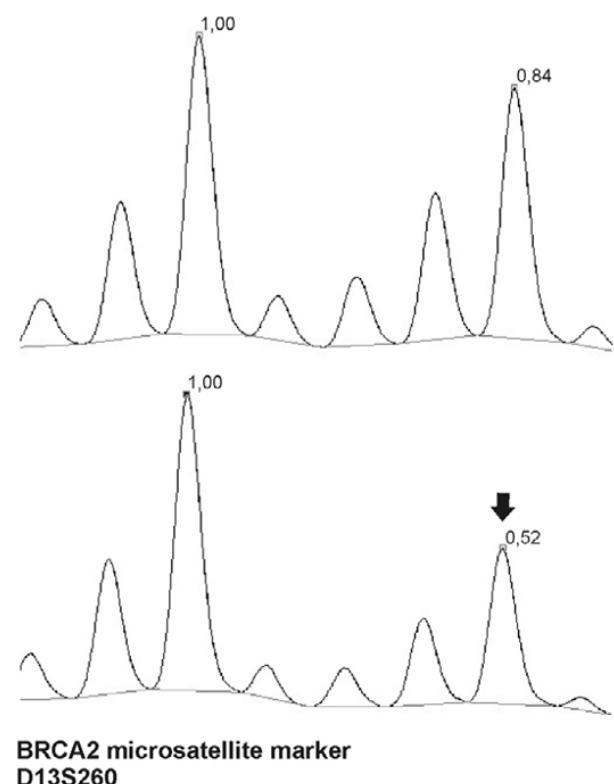

Allelic imbalance analysis at the BRCA loci. The electropherograms represent quantification of PCR products from normal DNA (upper) and tumour DNA (lower) from the same individual. A signal reduction is evident in the tumour electropherograms, which suggest allelic imbalance (indicated by an arrow) at the (a) BRCA1 locus, using the D17S1323 marker, and (b) BRCA2 locus, using the D13S260 marker.

Tissue sections were deparaffinized, placed in $0.01 \mathrm{M}$ citric acid solution $(\mathrm{pH} 6)$ and heated for $2 \times 10$ minutes in a microwave oven at maximum power. After cooling, tissue sections were incubated with pepsin at $37^{\circ} \mathrm{C}$ for 20 minutes followed by dehydration. Probes were diluted in t-DenHyb-2 hybridisation buffer (InSitus Biotechnologies, Albuquerque, NM, USA) as described by the manufacturer. Tissue section chromosomes and probes were simultaneously denatured at $95^{\circ} \mathrm{C}$ for 10 minutes. This was followed by overnight hybridisation at $37^{\circ} \mathrm{C}$ in a humid chamber and washing of tissue sections for $3 \times 5 \mathrm{~min}$ in $0.1 \mathrm{X} \mathrm{SSC}$ (Saline-Sodium-Citrate) at $60^{\circ} \mathrm{C}$ and mounting with 4'-6-Diamidino-2-phenylindole (DAPI) counterstaining. Fluorescence signals were scored in each sample by counting the number of single-copy gene and centromeric signals in at least 100 well-defined nuclei. Deletion of BRCA1 was defined if the copy number ratio was 0.8 or less, which has previously been used to detect deletion [30]. Deletion of chromosome 17 was defined if both BRCA1 and centromere mean copy numbers were 1.5 or less.

\section{Immunohistochemistry}

BRCA1 protein expression analysis was performed on formalin fixed and paraffin embedded malignant breast tissue and adjacent normal tissue (sliced in $4 \mu \mathrm{m}$ sections), with BRCA1 MS110 antibody (Oncogene Research Products, San Diego, CA, USA). Tissue sections were deparaffinized, placed in 0.01 $M$ citric acid solution $(\mathrm{pH} 6)$ and heated for $2 \times 10$ minutes in a microwave oven at maximum power. The sections were then incubated in $3 \% \mathrm{H}_{2} \mathrm{O}_{2}$ in order to block endogenous peroxidase activity. The BRCA1 MS110 antibody $(100 \mu \mathrm{g} / \mathrm{ml})$ was used in 1:50 dilution in 1X Tris buffer and incubated in a humid chamber at room temperature overnight. For antibody detection all slides were incubated with StreptABComplex/HRP Duet, Mouse/Rabbit Kit (Code No. K0492: Dako, Glostrup, Denmark) reagents following the manufacturer's recommendations. Counterstaining was performed with haemotoxylin.

Positive staining of normal breast epithelial cells that either coexisted on the tumour sections and/or normal breast tissue sections from the same breast was used as a control. The protein expression levels in tumour sections were measured by eye in three discontinuous classes, as previously described [31]. When the immunoreactivity was comparable to that of the normal breast epithelium or nuclear staining was observed in $>50 \%$ of tumour cells, it was classified as level 3 , that is, wild-type expression. When the staining was clearly weaker than normal surrounding cells or nuclear staining occurred in $20 \%$ to $50 \%$ of tumour cells, it was classified as level 2 , that is, reduced expression. When there was no staining or nuclear staining occurred in $<20 \%$ of tumour cells, it was classified as level 1 , that is, absent/markedly reduced expression.

\section{TP53 mutation analysis}

TP53 mutation analysis was carried out by PCR amplification and constant denaturing gel electrophoresis on exons 5-8. Mutations were confirmed by direct DNA sequencing in an 
Table 1

\begin{tabular}{|c|c|c|c|}
\hline \multirow[t]{2}{*}{ Primary sporadic breast tumours } & \multicolumn{2}{|c|}{$B R C A 1$ promoter methylation } & \multirow[t]{2}{*}{$P$ value } \\
\hline & Yes $(n=13)$ & No $(n=130)$ & \\
\hline \multicolumn{4}{|l|}{$\mathrm{Al}$ at the $B R C A 1$ locus } \\
\hline Yes & $8(62 \%)$ & $41(35 \%)$ & \\
\hline No & $5(38 \%)$ & $77(65 \%)$ & 0.0731 \\
\hline ND/NA & & 12 & \\
\hline \multicolumn{4}{|l|}{$\mathrm{Al}$ at the $B R C A 2$ locus } \\
\hline Yes & $5(38 \%)$ & $37(30 \%)$ & \\
\hline No & $8(62 \%)$ & $85(70 \%)$ & 0.5420 \\
\hline ND/NA & & 8 & \\
\hline \multicolumn{4}{|l|}{ TP53 mutations } \\
\hline Mutated TP53 gene & $5(38 \%)$ & $22(17 \%)$ & \\
\hline Wild type & $8(62 \%)$ & $106(83 \%)$ & 0.1299 \\
\hline ND/NA & & 2 & \\
\hline \multicolumn{4}{|l|}{ Estrogen receptor } \\
\hline Negative & $7(54 \%)$ & $33(25 \%)$ & \\
\hline Positive & $6(46 \%)$ & $97(75 \%)$ & 0.0475 \\
\hline \multicolumn{4}{|l|}{ ND/NA } \\
\hline \multicolumn{4}{|l|}{ Progesterone receptor } \\
\hline Negative & $6(50 \%)$ & $57(44 \%)$ & \\
\hline Positive & $6(50 \%)$ & $72(56 \%)$ & 0.7699 \\
\hline ND/NA & 1 & 1 & \\
\hline \multicolumn{4}{|l|}{ Age at diagnosis } \\
\hline$\leq 55$ years & $9(69 \%)$ & $57(44 \%)$ & \\
\hline$>55$ years & $4(31 \%)$ & $73(56 \%)$ & 0.0898 \\
\hline
\end{tabular}

Al, allelic imbalance; ND/NA, not determined/not available.

ALF Express DNA Sequencer (Amersham Pharmacia) as previously described [32].

\section{Statistical analysis}

Proportions were compared by two-tailed Fisher's exact test using GraphPad InStat3 (GraphPad Software Inc., San Diego, CA, USA). Associations with $P$ values of $<0.05$ were considered to be significant and $P$ values within the range of 0.05 to 0.10 as an indication of an association.

\section{Results}

Methylation of the BRCA1 promoter

Hypermethylation of the BRCA1 $\alpha$ promoter was assayed in 143 primary sporadic breast tumours. Methylation was detected in $9.1 \%(13 / 143)$ of the tumours (Figure 1$)$.

\section{Allelic imbalance at the BRCA1 and BRCA2 loci}

$\mathrm{Al}$ in the BRCA1 region was assessed in all 143 samples (Figure $2 a, b)$. The frequencies of informative cases for polymorphism at the BRCA1 microsatellite marker regions were $72.7 \%$ (D17S846), 89.5\% (D17S855) and $40.6 \%$ 


\section{Figure 3}
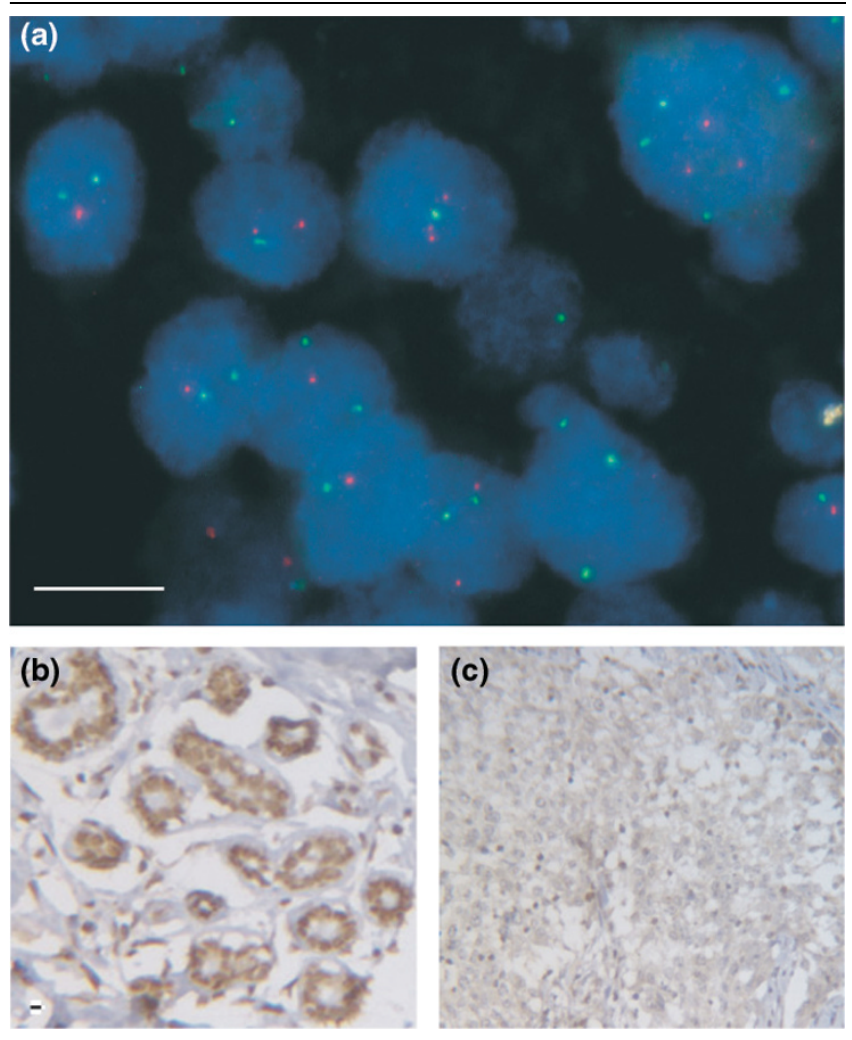

$B R C A 1$ gene copy number and protein expression analysis on breast tumor sections. (a) Tumor cells in a BRCA1 methylated sample are seen to have reduced $B R C A 1$ gene copy numbers (red signal) compared with centromere 17 (green signal) by FISH. Considerable heterogeneity in $B R C A 1$ gene copy numbers was evident in all tumours analysed. (b) A BRCA1 methylated tumour section showing wild-type BRCA1 protein expression by immunostaining in normal breast ducts and (c) absent/markedly reduced BRCA1 protein expression in tumour cells. Bars $=7 \mu \mathrm{m}$

(D17S1323). The intragenic markers D17S855 and D17S1323 showed $\mathrm{Al}$ in $35.2 \%$ and $43.1 \%$ of informative cases, respectively (Additional file 1). The exogenic marker D17S846 showed $\mathrm{Al}$ in $36.5 \%$ of informative cases. $\mathrm{Al}$ at the $B R C A 1$ locus was defined if one or both of the intragenic markers (D17S855, D17S1323) displayed Al. According to this definition, 37.4\% (49/131) of informative tumours had Al at the BRCA1 locus. Of these 49 tumours, 24 were informative for both intragenic markers, of which all but one displayed $\mathrm{Al}$ at both regions (95.8\%). Of the cases informative for an intragenic marker and the exogenic marker D17S846 $(n=33)$, $87.9 \%$ displayed $\mathrm{Al}$ at both regions.

An indication was found for an association between $B R C A 1$ methylation and $\mathrm{Al}$ at the $B R C A 1$ locus $(\mathrm{P}=0.0731$, odds ratio $(\mathrm{OR})=3.0,95 \%$ confidenece interval $(\mathrm{Cl})=0.9-9.8$; Table 1). Of the eight BRCA1 methylated tumours that displayed $\mathrm{Al}$ at the BRCA1 locus, five were informative for an intragenic marker and the exogenic marker. All these five tumours displayed $\mathrm{Al}$ at both regions.
The frequencies of informative cases for polymorphism at the BRCA2 microsatellite marker regions D13S260 and D13S171 were $74.1 \%$ and $71.3 \%$, respectively. The D13S260 marker showed $\mathrm{Al}$ in 32.1\% of informative cases, and the D13S171 marker in 35.3\% of informative cases (Additional file 1). Al at the BRCA2 locus was defined if one or both markers displayed Al. According to this definition, 31.1\% (42/ 135) of informative tumours had $\mathrm{Al}$ at the BRCA2 locus. Of these 42 tumours, 29 were informative for both markers, of which all but one displayed $\mathrm{Al}$ at both regions (96.6\%).

Al at the BRCA1 locus was found to be strongly associated with $\mathrm{Al}$ at the $B R C A 2$ locus $(\mathrm{P}<0.0001, \mathrm{OR}=7.0,95 \% \mathrm{Cl}=$ 3.0-16.4) with 26 of 124 (21.0\%) informative tumours having $\mathrm{Al}$ at both loci (Table 1). However, Al at the BRCA2 locus was not found to be associated with BRCA1 methylation ( $\mathrm{P}=$ $0.5420, \mathrm{OR}=1.4,95 \% \mathrm{Cl}=0.3-5.3$ ).

\section{FISH analysis at the BRCA1 locus}

$B R C A 1$ gene copy number was determined in the BRCA1 methylated tumours by FISH analysis (Additional file 1). Considerable heterogeneity was evident in the nuclei of these tumour cells (Figure 3a).

A physical deletion was detected at the BRCA1 locus in six tumours, including four with deletion of chromosome 17 (Table 2). Of these six tumours, all but one (sample 6 in Table 2) showed $\mathrm{Al}$ at the $B R C A 1$ locus.

\section{BRCA1 protein expression}

BRCA1 protein expression was estimated in all BRCA1 methylated tumours by immunostaining. Nine of the methylated tumours were estimated to have class 1 BRCA1 protein expression, indicating absent or markedly reduced BRCA1 expression (Figure 3b,c; Table 2). Of these nine tumours, all but two had $\mathrm{Al}$ at the BRCA1 locus (Table 2). Four tumours were estimated to have class 2 or 3 BRCA1 protein expression (Table 2). Of these four tumours, Al at the BRCA1 locus was detected in one case (Table 2).

\section{TP53 mutation analysis}

Of the 143 primary sporadic breast tumours in this study, 141 were available for TP53 mutation analysis. Mutation was found in $19.1 \%(27 / 141)$ of the tumours. Although not statistically significant, we found the frequency of TP53 mutations to be much higher within the subset of $B R C A 1$ methylated tumours compared with the non-methylated $B R C A 1$ tumours or $38.5 \%$ $(5 / 13)$ compared to $17.2 \%(22 / 128)$, respectively $(P=$ $0.1299, \mathrm{OR}=3.0,95 \% \mathrm{Cl}=0.9-10.1$; Table 1 ). However, TP53 mutations were only found in those BRCA1 methylated tumours that exhibited absent or markedly reduced BRCA1 expression, in which case the TP53 mutation frequency becomes $55.5 \%$ (5 of 9 ) and the association statistically significant $(P=0.01317, O R=6.13,95 \% \mathrm{Cl}=1.21-33.51$; Table 2). All the five tumours with $B R C A 1$ methylation and 
Table 2

\begin{tabular}{|c|c|c|c|c|c|c|c|c|}
\hline Tumour number & $\mathrm{Al}$ at $B R C A 1$ & $\mathrm{Al}$ at $B R C A 2$ & TP53 mutation & ER status & PR status & $\begin{array}{l}\text { BRCA1 protein } \\
\text { expressiona }\end{array}$ & DNA index & Interpretation of FISH \\
\hline 1 & + & - & - & + & + & 1 & NA & Deletion of the $B R C A 1$ region \\
\hline 2 & + & - & - & - & - & 1 & 1.68 & Deletion of the $B R C A 1$ region \\
\hline 3 & + & + & + & - & - & 1 & $1.12 ; 1.99$ & Chromosome 17 deletion \\
\hline 4 & + & + & + & - & - & 1 & 1.54 & Chromosome 17 deletion \\
\hline 5 & + & + & + & + & + & 1 & $1.22 ; 2.18$ & Chromosome 17 deletion \\
\hline 6 & - & - & - & + & + & 1 & NA & Chromosome 17 deletion \\
\hline 7 & + & - & + & - & - & 1 & 3.32 & No detectable $B R C A 1$ deletion \\
\hline 8 & - & - & - & + & + & 1 & $1.11 ; 1.80$ & No detectable $B R C A 1$ deletion \\
\hline 9 & + & + & + & - & - & 1 & 1.00 & No detectable $B R C A 1$ deletion \\
\hline 10 & - & - & - & + & + & 2 & 1.69 & No detectable $B R C A 1$ deletion \\
\hline 11 & - & - & - & - & - & 3 & 1.00 & No detectable $B R C A 1$ deletion \\
\hline 12 & - & - & - & + & + & 3 & 2.09 & No detectable $B R C A 1$ deletion \\
\hline 13 & + & + & - & - & NA & 3 & NA & No detectable $B R C A 1$ deletion \\
\hline
\end{tabular}

aBRCA1 protein expression in class 1 represents markedly reduced or absent expression; expression levels in class 2 and class 3 represent reduced and wild-type expression, respectively. Al, allelic imbalance; ER, estrogen receptor; NA, not available; PR, progesterone receptor.

TP53 mutation were found to have Al at the BRCA1 locus (Table 2). Furthermore, all five tumours showed absent or markedly reduced BRCA1 protein expression (Table 2).

\section{Hormonal receptor status and age at diagnosis}

Association was found between a negative ER status and $B R C A 1$ methylation $(\mathrm{P}=0.0475, \mathrm{OR}=3.4,95 \% \mathrm{Cl}=1.1-$ 10.9; Table 1). No associations were found between BRCA1 methylation and a negative/positive PR status.

An indication for an association between young age $(=55)$ at diagnosis and BRCA1 methylation was found $(P=0.0898$, $\mathrm{OR}=2.9,95 \% \mathrm{Cl}=0.8-13.4$ ).

\section{Tumour grade and histological type}

Of all the 13 BRCA1 methylated tumours, seven were of grade 3 , five of grade 2 and one of grade 1. All BRCA1 methylated tumours were of infiltrating ductal type except for one that was of a lobular type.

\section{Discussion}

We report here that hypermethylation of the $B R C A 1$ gene promoter is found in a considerable proportion of primary sporadic breast carcinomas, that is, 13 of $143(9.1 \%)$, which is in the lower end of previously reported frequencies for this alteration in sporadic breast tumours $[14,33,34]$.

Absent or markedly reduced BRCA1 protein expression was evident in the majority of the $B R C A 1$ methylated tumours ( 9 of $13)$, suggesting transcriptional silencing in these tumours by epigenetic modifications. $\mathrm{A}$ trend for $\mathrm{Al}$ at the $B R C A 1$ locus was observed in the subset of $B R C A 1$ methylated tumours $(P$ $=0.0731$ ). All the BRCA1 methylated tumours that had $\mathrm{Al}$ at the $B R C A 1$ locus and were informative for $\mathrm{Al}$ at the exogenic and an intragenic marker displayed $\mathrm{Al}$ at both regions, indicating a rather large deletion at chromosome 17 . This is supported by the FISH analysis, which revealed deletion of chromosome 17 in most of the BRCA1 methylated tumours that had a detectable $B R C A 1$ deletion. Importantly, the FISH analysis revealed substantial heterogeneity in $B R C A 1$ gene copy numbers between individual cells in the BRCA1 methylated tumours, demonstrating that $\mathrm{Al}$ as detected by polymorphic microsatellite PCR analysis does not infer a simple loss of one $B R C A 1$ allele but, rather, it appears to reflect complex genetic rearrangements.

Al at the BRCA1 and BRCA2 loci are know to be relatively common in breast tumours [8]. The implications of $\mathrm{Al}$ at the $B R C A 1$ and/or BRCA2 loci for sporadic breast tumorigenesis remain unknown since Knudson's hypothesis predicts that two 'hits' are required for tumorigenesis to occur [9]. Our results confirm that $\mathrm{Al}$ at the BRCA1 and BRCA2 loci are common events in sporadic breast tumours, present in $37.4 \%(49 / 131)$ and $31.1 \%(42 / 135)$ of primary sporadic breast tumours, respectively. A significant association was found between $\mathrm{Al}$ at the $B R C A 1$ and $B R C A 2$ loci $(P<0.0001)$. Importantly, we found an indication for $\mathrm{Al}$ at the $B R C A 1$ locus to be associated with $B R C A 1$ methylation $(P=0.0731)$ whereas $\mathrm{Al}$ at the $B R C A 2$ locus was not found to be associated with $B R C A 1$ methylation $(P=0.5420)$. This has not been shown previously and suggests that $\mathrm{Al}$ at the BRCA1 locus is specifically associated with BRCA1 methylation. Thus, copy number altera- 
tions and epigenetic silencing of the BRCA1 gene in sporadic breast cancer could serve as Knudson's 'hits', which has previously been proposed by Esteller and colleagues [35]. Indeed, all but one of the BRCA1 methylated tumours that had absent/markedly reduced BRCA1 protein expression (8 of 9) also had a detectable deletion of the BRCA1 gene. Collectively, these results suggest that the BRCA1 gene is implicated in sporadic breast tumorigenesis through epigenetic silencing and deletion of the BRCA1 gene. Indications that $B R C A 1$ methylation is important in hereditary breast cancer have been reported [35].

The failure to detect a $B R C A 1$ deletion in one of the tumours that exhibited absent or markedly reduced BRCA1 expression could mean that promoter hypermethylation is present on both alleles, thereby alleviating any selection pressure for deletion at the BRCA1 locus. Alternatively, the level of detection in the FISH analysis could be limited by the small proportion of tumour cells present in each tumour section analysed. This might also apply for those tumours in which $\mathrm{Al}$ was present without a detectable deletion by FISH. Conversely, the detection level of the $\mathrm{Al}$ analysis was limited by the fact that none of the tumours were micro/macrodissected prior to DNA isolation, which also means that unmethylated BRCA1 alelles are always detected in the tumour samples due to the presence of normal DNA.

The four BRCA1 methylated tumours that did not exhibit significantly reduced BRCA1 expression could possibly be heterogenous with respect to this alteration. None of the four tumours exhibited BRCA1 deletion by $\mathrm{FISH}$ and only one displayed $\mathrm{Al}$ at the BRCA1 locus. Alternatively, DNA methylation might not bring about transcriptional silencing in all instances.

Although the etiology of cancer predisposition in individuals carrying a germline BRCA1 mutation is not clear, increased genomic instability in BRCA1 deficient cells is undoubtedly of importance since it is predicted to result in increased probability of further genetic alterations and gene mutations, which might result in functional consequences by which tumorigenic potential could be acquired. Genomic instability, however, is a potent inducer of apoptosis where cell survival is dependent upon dysfunctional checkpoint mechanisms [4]. Indeed, familial BRCA1 tumours are associated with mutations in the TP53 checkpoint gene, supporting the notion that genomic instability is an important driving force in early-onset familial $B R C A 1$ tumorigenesis [5]. Association of BRCA1 methylation with TP53 mutations has not been shown previously. Our results show a higher frequency of TP53 mutations among the $B R C A 1$ methylated tumours compared with the non-methylated tumours or $38.5 \%$ (5 of 13) and $17.2 \%$ (22 of 128), respectively $(P=0.1299, O R=3.0,95 \% \mathrm{Cl}=0.9-10.1)$. This association was not statistically significant, although the TP53 mutations were found to be entirely limited to those BRCA1 methylated tumours that exhibited absent or markedly reduced
BRCA1 expression, in which case the frequency of TP53 mutations becomes $55.5 \%$ (5 of 9 ) and the association statistically significant $(\mathrm{P}=0.01317, \mathrm{OR}=6.13,95 \% \mathrm{Cl}=1.21-$ 33.51). Reinforcing this idea is the observation that all the five BRCA1 methylated tumours with a TP53 mutation had a detectable BRCA1 copy number reduction and the majority of these tumours had a relatively high DNA index, suggesting genomic instability (Table 2).

It has previously been suggested that $B R C A 1$ methylated tumours might phenocopy familial BRCA1 tumours [36]. In support of this notion, we observed ER negativity to be significantly associated with $B R C A 1$ methylation $(P=0.0475)$, a well established characteristic of familial BRCA1 tumours previously reported by Catteau and colleagues [37] and others. However, Matros and colleagues [24], looking at gene expression profiles, found a high frequency of BRCA1 promoter methylation among high-grade ER positive tumours, suggesting a more complex phenotype association. We found an indication for BRCA1 methylation to be specifically associated with $\mathrm{Al}$ at the BRCA1 locus and an elevated frequency of TP53 mutations, which has not been reported previously. In addition, we found a considerable proportion of the BRCA1 methylated tumours (7 of 13) to be of grade 3 , with only one tumour of grade 1 , as well as an indication of an association between BRCA1 methylation and an early age of onset $(P=$ 0.0898 ) as previously reported by Wei and colleagues [34].

It has been suggested that breast cancers arising in individuals carrying a germline mutation in the BRCA genes could benefit from therapeutic agents that lead to DNA cross-links or double-strand breaks at replication forks, for example, mitomycin $\mathrm{C}$, cisplatin, diepoxybutane and, more recently, poly(ADPribose) polymerase (PARP) inhibitors [38]. These therapeutic agents could also be effective for sporadic breast cancers with abnormalities in the BRCA genes, which is, as shown here, a considerably larger proportion of all breast cancer patients than germline $B R C A 1$ or $B R C A 2$ mutation carriers. In addition, abnormalities in other genes regulating homologous recombination could also be of relevance. This emphasizes the importance of developing methods for identifying BRCA-like cancers, regardless of the underlying alterations [36].

\section{Conclusion}

Our results show promoter hypermethylation of the BRCA1 gene in a considerable proportion of all primary sporadic breast tumours. The majority of the BRCA1 methylated tumours were found to have absent or markedly reduced BRCA1 expression, suggesting transcriptional silencing by epigenetic modifications. In addition, we found an indication for $\mathrm{Al}$ at the BRCA1 locus to be associated with BRCA1 methylation whereas $\mathrm{Al}$ at the BRCA2 locus was not associated with BRCA1 methylation. This indicates that $\mathrm{Al}$ at the $B R C A 1$ locus is specifically associated with $B R C A 1$ methylation. The genetic alterations at the BRCA1 locus were further 
examined by $\mathrm{FISH}$, which revealed chromosome 17 deletions and heterogeneity with respect to chromosomal abnormalities. These results imply that methylation of the $B R C A 1$ gene is accompanied by genomic rearrangements at the BRCA1 locus, resulting in loss of genetic material containing nonmethylated BRCA1 alleles and retention of methylated $B R C A 1$ alleles. We also found a substantially elevated frequency of TP53 mutations in the subset of BRCA1 methylated tumours, which has not been reported previously, suggesting that $B R C A 1$ methylation might lead to alterations in the same molecular pathways as those known to be commonly altered in familial BRCA1 tumours. Collectively, these results implicate epigenetic silencing of the BRCA1 gene in sporadic breast tumorigenesis.

Medullary histological type was not found in the BRCA1 methylated tumours. However, we observed ER negativity to be significantly associated with BRCA1 methylation. We also found a substantial proportion of the BRCA1 methylated tumours to be of grade 3 and an indication for an association between $B R C A 1$ methylation and early age of onset. Thus, our results indicate phenotypic similarities between BRCA1 methylated and familial BRCA1 breast tumours.

\section{Competing interests}

The authors declare that they have no competing interests.

\section{Authors' contributions}

VB and OAS contributed equally to this work, performing a substantial part of the analysis, participation in design and contribution to the writing of the manuscript. SKB contributed to $\mathrm{FISH}$ analysis, $\mathrm{HH}$ to TP53 analysis and JGJ to supervision and analysis of pathological data and immunostaining. JEE conceived of the study, was in charge of its design and coordination and the writing of the manuscript. All authors read and approved the final manuscript.

\section{Additional files}

The following Additional files are available online:

\section{Additional file 1}

An Excel file containing results of the FISH analysis along with DNA index and proportion of aneuploid cells.

See http://www.biomedcentral.com/content/

supplementary/bcr1522-S1.xls

\section{Additional file 2}

An Excel file containing results for each of the microsattelite markers analysed for Al.

See http://www.biomedcentral.com/content/ supplementary/bcr1522-S2.xls

\section{Acknowledgements}

We thank the Department of Pathology and The Icelandic University Hospital for their collaboration, the Icelandic Cancer Society Biobank for supplying samples, Professor Magnus Johannsson for statistical advise and Gudridur Olafsdottir for data management. This work was supported by The University of Iceland Research Fund, Icelandic Research Foundation Graduate Student Grants (VB, OAS, SKB). The memorial fund of Bergthora Magnusdottir and Jakob Bjarnason (SKB), and The Icelandic Cancer Society.

\section{References}

1. Arver B, Du Q, Chen J, Luo L, Lindblom A: Hereditary breast cancer: a review. Semin Cancer Biol 2000, 10:271-288.

2. Collins N, McManus R, Wooster R, Mangion J, Seal S, Lakhani SR, Ormiston W, Daly PA, Ford D, Easton DF, et al:: Consistent loss of the wild type allele in breast cancers from a family linked to the BRCA2 gene on chromosome 13q12-13. Oncogene 1995, 10:1673-1675.

3. Smith SA, Easton DF, Evans DG, Ponder BA: Allele losses in the region 17q12-21 in familial breast and ovarian cancer involve the wild-type chromosome. Nat Genet 1992, 2:128-131.

4. Scully R, Livingston DM: In search of the tumour-suppressor functions of BRCA1 and BRCA2. Nature 2000, 408:429-432.

5. Greenblatt MS, Chappuis PO, Bond JP, Hamel N, Foulkes WD: TP53 mutations in breast cancer associated with BRCA1 or BRCA2 germ-line mutations: distinctive spectrum and structural distribution. Cancer Res 2001, 61:4092-4097.

6. Futreal PA, Liu Q, Shattuck-Eidens D, Cochran C, Harshman K, Tavtigian S, Bennett LM, Haugen-Strano A, Swensen J, Miki Y, et al.: BRCA1 mutations in primary breast and ovarian carcinomas. Science 1994, 266:120-122.

7. Lancaster JM, Wooster R, Mangion J, Phelan CM, Cochran C Gumbs C, Seal S, Barfoot R, Collins N, Bignell G, et al.: BRCA2 mutations in primary breast and ovarian cancers. Nat Genet 1996, 13:238-240.

8. Johnson SM, Shaw JA, Walker RA: Sporadic breast cancer in young women: prevalence of loss of heterozygosity at p53, BRCA1 and BRCA2. Int J Cancer 2002, 98:205-209.

9. Knudson AG Jr: Mutation and cancer: statistical study of retinoblastoma. Proc Natl Acad Sci USA 1971, 68:820-823.

10. Herman JG, Baylin SB: Gene silencing in cancer in association with promoter hypermethylation. $N$ Engl J Med 2003, 349:2042-2054.

11. Jones PA, Baylin SB: The fundamental role of epigenetic events in cancer. Nat Rev Genet 2002, 3:415-428.

12. Esteller M, Corn PG, Baylin SB, Herman JG: A gene hypermethylation profile of human cancer. Cancer Res 2001, 61:3225-3229.

13. Feinberg AP: The epigenetics of cancer etiology. Semin Cancer Biol 2004, 14:427-432.

14. Esteller M, Silva JM, Dominguez G, Bonilla F, Matias-Guiu X, Lerma E, Bussaglia E, Prat J, Harkes IC, Repasky EA, et al:: Promoter hypermethylation and BRCA1 inactivation in sporadic breast and ovarian tumors. J Natl Cancer Inst 2000, 92:564-569.

15. Collins N, Wooster R, Stratton MR: Absence of methylation of CpG dinucleotides within the promoter of the breast cancer susceptibility gene BRCA2 in normal tissues and in breast and ovarian cancers. Br J Cancer 1997, 76:1150-1156.

16. Hilton JL, Geisler JP, Rathe JA, Hattermann-Zogg MA, DeYoung B, Buller RE: Inactivation of BRCA1 and BRCA2 in ovarian cancer. J Natl Cancer Inst 2002, 94:1396-1406.

17. Hedenfalk I, Duggan D, Chen Y, Radmacher M, Bittner M, Simon R, Meltzer P, Gusterson B, Esteller M, Kallioniemi OP, et al:: Geneexpression profiles in hereditary breast cancer. $N$ Engl J Med 2001, 344:539-548.

18. Lakhani SR, Jacquemier J, Sloane JP, Gusterson BA, Anderson TJ van de Vijver MJ, Farid LM, Venter D, Antoniou A, Storfer-Isser A, et al.: Multifactorial analysis of differences between sporadic breast cancers and cancers involving BRCA1 and BRCA2 mutations. J Natl Cancer Inst 1998, 90:1138-1145.

19. Honrado E, Benitez J, Palacios J: The molecular pathology of hereditary breast cancer: genetic testing and therapeutic implications. Mod Pathol 2005, 18:1305-1320. 
20. Loman N, Johannsson O, Bendahl PO, Borg A, Ferno M, Olsson $\mathrm{H}$ : Steroid receptors in hereditary breast carcinomas associated with BRCA1 or BRCA2 mutations or unknown susceptibility genes. Cancer 1998, 83:310-319.

21. Eisinger F, Stoppa-Lyonnet D, Longy M, Kerangueven F, Noguchi T, Bailly C, Vincent-Salomon A, Jacquemier J, Birnbaum D, Sobol $\mathrm{H}$ : Germ line mutation at BRCA1 affects the histoprognostic grade in hereditary breast cancer. Cancer Res 1996, 56:471-474.

22. van 't Veer $L J$, Dai $H$, van de Vijver MJ, He YD, Hart AA, Mao M, Peterse HL, van der Kooy K, Marton MJ, Witteveen AT, et al.: Gene expression profiling predicts clinical outcome of breast cancer. Nature 2002, 415:530-536.

23. Alvarez S, Diaz-Uriarte R, Osorio A, Barroso A, Melchor L, Paz MF, Honrado E, Rodriguez R, Urioste M, Valle L, et al:: A predictor based on the somatic genomic changes of the BRCA1/BRCA2 breast cancer tumors identifies the non-BRCA1/BRCA2 tumors with BRCA1 promoter hypermethylation. Clin Cancer Res 2005, 11:1146-1153.

24. Matros E, Wang ZC, Lodeiro G, Miron A, Iglehart JD, Richardson AL: BRCA1 promoter methylation in sporadic breast tumors: relationship to gene expression profiles. Breast Cancer Res Treat 2005, 91:179-186.

25. Bergthorsson JT, Jonasdottir A, Johannesdottir G, Arason A, Egilsson V, Gayther S, Borg A, Hakanson S, Ingvarsson S, Barkardottir RB: Identification of a novel splice-site mutation of the BRCA1 gene in two breast cancer families: screening reveals low frequency in Icelandic breast cancer patients. Hum Mutat 1998:S195-197.

26. Thorlacius S, Olafsdottir G, Tryggvadottir L, Neuhausen S, Jonasson JG, Tavtigian SV, Tulinius H, Ogmundsdottir HM, Eyfjord JE: A single BRCA2 mutation in male and female breast cancer families from Iceland with varied cancer phenotypes. Nat Genet 1996, 13:117-119.

27. Herman JG, Graff JR, Myohanen S, Nelkin BD, Baylin SB: Methylation-specific PCR: a novel PCR assay for methylation status of CpG islands. Proc Natl Acad Sci USA 1996, 93:9821-9826.

28. Baldwin RL, Nemeth E, Tran H, Shvartsman H, Cass I, Narod S Karlan BY: BRCA1 promoter region hypermethylation in ovarian carcinoma: a population-based study. Cancer Res 2000, 60:5329-5333.

29. GDB Human Genome Data Base [http://www.gdb.org]

30. Staff S, Nupponen NN, Borg A, Isola JJ, Tanner MM: Multiple copies of mutant BRCA1 and BRCA2 alleles in breast tumors from germ-line mutation carriers. Genes Chromosomes Cancer 2000, 28:432-442.

31. Wilson CA, Ramos L, Villasenor MR, Anders KH, Press MF, Clarke K, Karlan B, Chen JJ, Scully R, Livingston D, et al.: Localization of human BRCA1 and its loss in high-grade, non-inherited breast carcinomas. Nat Genet 1999, 21:236-240.

32. Gudlaugsdottir S, Sigurdardottir V, Snorradottir M, Jonasson JG, Ogmundsdottir H, Eyfjord JE: P53 mutations analysis in benign and malignant breast lesions: using needle rinses from fineneedle aspirations. Diagn Cytopathol 2000, 22:268-274.

33. Staff S, Isola J, Tanner M: Haplo-insufficiency of BRCA1 in sporadic breast cancer. Cancer Res 2003, 63:4978-4983.

34. Wei M, Grushko TA, Dignam J, Hagos F, Nanda R, Sveen L, Xu J, Fackenthal J, Tretiakova M, Das S, et al.: BRCA1 promoter methylation in sporadic breast cancer is associated with reduced BRCA1 copy number and chromosome 17 aneusomy. Cancer Res 2005, 65:10692-10699.

35. Esteller M, Fraga MF, Guo M, Garcia-Foncillas J, Hedenfalk I, Godwin AK, Trojan J, Vaurs-Barriere C, Bignon YJ, Ramus S, et al:: DNA methylation patterns in hereditary human cancers mimic sporadic tumorigenesis. Hum Mol Genet 2001, 10:3001-3007.

36. Turner N, Tutt A, Ashworth A: Hallmarks of 'BRCAness' in sporadic cancers. Nat Rev Cancer 2004, 4:814-819.

37. Catteau A, Harris WH, Xu CF, Solomon E: Methylation of the BRCA1 promoter region in sporadic breast and ovarian cancer: correlation with disease characteristics. Oncogene 1999 , 18:1957-1965.

38. Turner N, Tutt A, Ashworth A: Targeting the DNA repair defect of BRCA tumours. Curr Opin Pharmacol 2005, 5:388-393. 